\title{
Sekcja Socjologii Etniczności PTS — nowa inicjatywa wrocławskich socjologów
} DOI: 10.19195/2083-7763.7.21

Zachodzące w ostatnich latach zdarzenia wydają się wskazywać, że żyjemy w czasach intensywnych przemian społeczno-kulturowych, które - co dla nas szczególnie istotne - nie omijają także sfery narodowo-etnicznej. Jednostki i grupy wciąż potrzebują typu wspólnoty odwołującej się do tego, co - jak mniemają - stanowi o ich odrębności, a może i unikalności. Dlatego, naszym zdaniem, na uwagę zasługuje myśl, którą sformułował Steve Fenton, rozważając status ontologiczny terminu „etnicznośćc:

Ludzie czy narody nie tylko mają kulturę lub wspólny rodowód; oni przekształcaja to $w$ ideę wspólnoty, zasadzająca się na tych elementach. Co więcej, wypracowanie idei wspólnoty jest wśród ludzi całkowicie możliwe pomimo tego, że ich przynależność do wspólnoty pochodzeniowej i kulturowej jest wątpliwa ${ }^{1}$.

Odwołując się do dorobku socjologii humanistycznej, zakładamy, że przeświadczenie to ma dla owych podmiotów znaczenie większe niż różnorakie deklaracje polityczne i że fakt ten będzie manifestować się w działaniach tych grup.

W tym klimacie intelektualnym w kręgu osób związanych z Zakładem Socjologii Pogranicza Instytutu Socjologii Uniwersytetu Wrocławskiego zrodziła się myśl o powołaniu do życia Sekcji Socjologii Etniczności Polskiego Towarzystwa Socjologicznego. Uzyskawszy poparcie dla tej idei ze strony ogólnopolskiego grona socjologów, do Zarządu Głównego PTS skierowaliśmy wniosek o utworzenie Sekcji. Miało to miejsce 28 lutego 2014 roku podczas posiedzenia ZG PTS w Warszawie, natomiast dwa miesiące później we Wrocławiu ukonstytuował się sześcioosobowy Zarząd Sekcji Socjologii Etniczności (SSE). Obecnie Sekcja liczy 46 członków (stan na 31 grudnia 2016 roku).

Sferę naszych zainteresowań zakreślamy dosyć szeroko, gdyż wyznaczają ją takie zagadnienia, jak: mniejszości, tożsamość, sąsiedztwa, migracje, wielokulturowość, środkowoeuropejskość oraz rozmaite ruchy i zbiorowości analizowane w kontekście etnicznym oraz narodowościowym. Zarazem jednak, wyznaczając geograficzno-polityczne ramy naszej aktywności, należy zaznaczyć, że uwagę swą koncentrujemy przede wszystkim na obszarze Europy Środkowo-Wschodniej, ze szczególnym uwzględnieniem rzeczywistości Polski. W tym sensie poprzez swą inicjatywę pragniemy nawiązać do dziewiętnastowiecznej socjologii środkowoeuropejskiej, która — jak pisał Jerzy Szacki — tematyce narodowościowej poświęciła dużo więcej uwagi niż myśliciele zachodnioeuropejscy².

Sens naszej inicjatywy sprowadza się do stworzenia płaszczyzny dla integracji środowiska socjologów zajmujących się tematyką etniczności (uczestnictwo w spotkaniach naukowych, seminariach itp.), a także do wspierania przedsięwzięć poświęconych tym kwestiom (m.in. konferencji, sympozjów, odczytów, publikacji). Organizując część z tych wydarzeń, Sekcja współpracowała z różnymi podmiotami. Autorską inicjatywą SSE są prelekcje odbywające się w ramach cyklu „Etno-spotkania”. Większość z nich odbyła się w Muzeum Etnograficznym we Wrocławiu, z którym Sekcja nawiązała współpracę w listopadzie 2014 roku.

\footnotetext{
${ }^{1}$ S. Fenton, Etniczność, przeł. E. Chomicka, Warszawa 2007, s. 12-14.

2 J. Szacki, Historia myśli socjologicznej, Warszawa 2002, s. 174.
} 
Dotychczas Sekcja Socjologii Etniczności PTS organizowała bądź współorganizowała następujące przedsięwzięcia:

— konferencję naukową „Sąsiedztwa III RP - Ukraina” (organizator: Instytut Socjologii UWr, kwiecień 2014);

- prelekcję w ramach „Etno-spotkań”: dr hab. Barbara Grabowska (Uniwersytet Śląski): Poczucie tożsamości młodych Polaków na Białorusi, Ukrainie i w Republice Czeskiej (grudzień 2014);

— prelekcję w ramach „Etno-spotkań”: mgr Andrij Yurkevych (Państwowy Uniwersytet Pedagogiczny w Drohobyczu): Pogranicze kultur. Międzynarodowy Festiwal Brunona Schulza jako przykład pojednania, współpracy oraz dialogu między narodami (marzec 2015);

— konferencję naukową "Sąsiedztwa III RP — Rosja” (organizator: Instytut Socjologii UWr, październik 2015);

— prelekcję w ramach „Etno-spotkań”: dr Elżbieta Szyszlak, dr Tomasz Szyszlak (Uniwersytet Wrocławski): Romowie w Czechach i w Polsce u progu XXI wieku (październik 2015);

- prelekcję w ramach „Etno-spotkań”: dr Nicolas Maslowski (Uniwersytet Karola w Pradze): Wielcy Czesi i Słowacy ostatnich 150 lat - na podstawie analiz prozopograficznych (listopad 2015);

- wieczór autorski: prof. dr hab. Beata Halicka (Uniwersytet Adama Mickiewicza w Poznaniu): Polski Dziki Zachód. Przymusowe migracje i kulturowe oswajanie Nadodrza, 1945-48 (organizatorzy: Ośrodek Badań Regionalnych i Obszarów Pogranicza, Centrum Studiów Niemieckich i Europejskich im. Willy’ego Brandta; grudzień 2015);

- dyskusję w ramach cyklu spotkań „Socjologiczne niedziele w Panato”: dr Marcin Dębicki (Uniwersytet Wrocławski), dr Mirosława Zielińska (Wrocław), prof. dr hab. Dariusz Wojakowski (Uniwersytet Rzeszowski): Między nami, sąsiadami. Niemcy, Czesi i Ukraincy - jak ich widzimy, jak widza nas? (organizator: o. Wrocław PTS, marzec 2016);

- międzynarodową konferencję naukową „Polskie pogranicza w procesie przemian”, cz. 4 (organizatorzy: Instytut Socjologii UWr, Ośrodek Badań Regionalnych i Obszarów Pogranicza; maj 2016);

- grupę tematyczną (jako współorganizator) Etniczne wyzwania naszych czasów w ramach XVI Ogólnopolskiego Zjazdu Socjologicznego PTS w Gdańsku (wrzesień 2016);

— prelekcję w ramach „Etno-spotkań”: dr Agata Chutnik (Uniwersytet Łódzki): Przyjazd litewskich Polaków na studia do Polski. Przemiany tożsamości (grudzień 2016);

— konferencję z cyklu „Sąsiedztwa III RP - Słowacja” (organizator: Instytut Socjologii UWr, grudzień 2016).

Sekcja ma swoją zakładkę na stronie internetowej Polskiego Towarzystwa Socjologicznego (http://pts.org.pl/sekcje/sekcja-socjologii-etnicznosci/). Pojawiają się tam informacje o wydarzeniach organizowanych przez Sekcję lub w które jest ona bezpośrednio zaangażowana; tym samym tworzone jest kalendarium podejmowanych przez nas aktywności. Informacje na temat naszej działalności zamieszczamy również na profilu SSE na facebooku (https://www.facebook.com/sse.pts), a także wybiórczo na stronach oddziałów PTS, których członkowie działają w naszej Sekcji (na przykład http://www.pts.wroclaw.pl) ${ }^{3}$.

\footnotetext{
${ }^{3}$ Kontakt z Sekcją: etnicznosc.pts@gmail.com.
} 
Jesteśmy przekonani, że realizowane przez nas przedsięwzięcie tworzy możliwość poszerzenia spektrum tematycznej aktywności członków PTS o zagadnienia dotychczas formalnie niewyodrębnione w ramach działalności Towarzystwa, które jednakże wciąż, mimo presji globalizacyjnej, nie tracą na aktualności. W związku z tym żywimy nadzieję, że również Sekcja Socjologii Etniczności - pozostając w łączności z innymi podmiotami skoncentrowanymi na sprawach etnicznych - będzie mogła zaznaczyć swój wkład w dzieło dalszego rozpoznania i objaśniania zjawisk kształtujących bieżące oblicze świata społecznego.

Marcin Dębicki, Kamilla Dolińska

Sekcja Socjologii Pracy Polskiego Towarzystwa Socjologicznego: w poszukiwaniu tożsamości polskiej socjologii pracy w XXI wieku

DOl: 10.19195/2083-7763.7.22

Sekcja Socjologii Pracy jest jedną z najstarszych sekcji Polskiego Towarzystwa Socjologicznego, powstałą w latach sześćdziesiatych XX wieku. W okresie realnego socjalizmu działalność Sekcji związana była przede wszystkim z aktywnością socjologów i socjolożek zakładowych, zatrudnionych w kluczowych przedsiębiorstwach państwowych w związku z podejmowanymi działaniami w ramach koncepcji humanizacji pracy. Po 1989 roku aktywność Sekcji uległa pewnemu wyciszeniu, na co złożyły się przemiany polityczno-gospodarcze, koniec ruchu socjologów zakładowych, a także procesy deinstytucjonalizacji socjologii pracy w sferze akademickiej. W 2013 roku starania na rzecz odbudowy aktywności Sekcji podjął jej nowy zarząd pod przewodnictwem Adama Mrozowickiego (Uniwersytet Wrocławski), w składzie: Joanna Róg-Ilnicka (wiceprzewodnicząca, Uniwersytet Zielonogórski), Zbigniew Galor (członek zarządu, Uniwersytet Szczeciński), Slaviana Holc (członek Zarządu, Instytut Filozofii i Socjologii PAN), Elżbieta Kolasińska (członek Zarządu i sekretarz, Uniwersytet Gdański), a od 2016 roku także Olga Czeranowska (członek Zarządu i skarbnik, Uniwersytet Warszawski).

Zasadnicze kierunki działalności Zarządu Sekcji Socjologii Pracy zostały wyznaczone przez (1) projekt cyklicznych konferencji międzynarodowych „Społeczne granice pracy”; (2) działalność publikacyjną, której celem była integracja środowiska socjologów pracy oraz promocja aktywności naukowej jego przedstawicieli i przedstawicielek; (3) projekt „Nestorzy socjologii pracy w Polsce”, poświęcony dokumentacji doświadczeń polskiej socjologii pracy w oparciu o wywiady biograficzne z elementami historii mówionej z przedstawicielami subdyscypliny, którzy swoją działalność rozpoczynali przed 1989 rokiem. Uzupełnieniem tych aktywności było zgłoszenie dwóch grup tematycznych na Ogólnopolskie Zjazdy Socjologiczne PTS: „Socjologia pracy - dialog między generacjami” (Szczecin 2013) oraz „Praca i gospodarka po kryzysie” (Gdańsk 2016). Utworzono profil Sekcji na portalu społecznościowym, a także stworzono listę mailową członków Sekcji. W 2016 roku Sekcja Socjologii Pracy wraz z nowo powstałą Sekcją Socjologii Ekonomicznej, a także przedstawicielami Instytutu Socjologii Uniwersytetu Warszawskiego, 